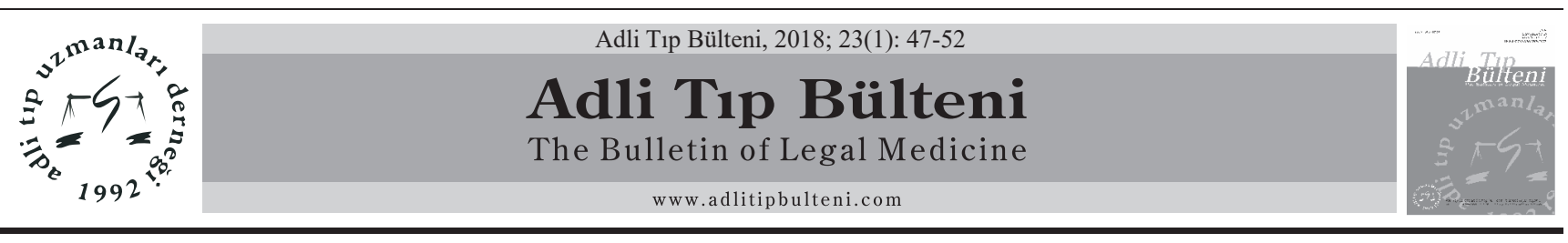

\title{
Adli Toksikolojik Analizlerde Alternatif Örnek: Tırnak
}

\section{An Alternative Specimen in Toxicological Analysis: Nail}

\author{
Pınar Efeoğlu Özşeker, Nebile Dă̆lıoğlu \\ Çukurova Üniversitesi Tıp Fakültesi Adli Tıp Anabilim Dalı, Adana
}

\section{Özet}

Son zamanlarda hassas ve seçici analitik tekniklerin gelişmesiyle beraber alternatif biyolojik örneklerin kullanımı artmıştır. Özellikle dekompoze ve pütrifiye olmuş postmortem vakalarda ya da kan veya idrar örneklerinin alınamadığı durumlarda saç ve tırnak gibi keratin yapılı biyolojik örnekler adli ve klinik toksikologların ilgisini çekmiştir.

İlaçlar, kimyasallar, uyutucu-uyuşturucu maddeler, ağır metaller uzun dönem saçta ve tırnakta birikebilmektedir. Geçmişe dönük kullanımda iyi bir belirteç olan saç örneğinin yetersiz olduğu durumlarda toksikolojik analiz için tırnak örneği yararlı olabilmektedir. Tırnak matrisinin kompleks yapısı ve tırnakta tespit edilen ilaç konsantrasyonunun düşük olması nedeniyle numune hazırlama işlemi ve kullanılacak olan analitik yöntemler önemlidir.

Bu çalışmada toksikolojik analizlerde alternatif olarak kullanılan tırnağın anatomik yapısı, tırnak analizlerindeki analitik yöntemler, tırnak kullanımın avantajları/dezavantajları ve analiz sonuçların nasıl yorumlanacağı incelenecektir.

Anahtar Kelimeler: Tırnak; Toksikolojik Analiz; Yorumlama.

\begin{abstract}
The use of alternative biological samples has increased with the development of sensitive and selective analytical techniques in recent days. Keratinous biological samples such as hair and nail have attracted the attention of clinical and forensic toxicologist when blood and urine sample especially were not taken in cases which were the decomposed and unfolded postmortem cases.

Drugs, medicines, drug of abuse and heavy metals may accumulate for a long time in hair and nail. The nail sample may be useful for toxicological analysis when the hair sample, which is a good marker for past use, is inadequate. Sample preparation and analytical methods to be used are important because of the complex structure of nail and low drug concentration detected in nail.
\end{abstract}

In this study, the basic structure of nail used as an alternative to toxicological analysis, the mechanism of drug or substance transfer into the nail, analytical methods, the advantages / disadvantages of nails and how to interpret the results will be examined.

Keywords: Nail; Toxicological Analysis; Interpretation.

\section{Giriş}

Klinik ve adli toksikoloji uygulamalarında rutinde kan ve idrar örnekleri kullanılmaktadır. Bu biyolojik örnekler kişinin yakın dönemdeki ilaç, alkol, ağır metal ve uyutucu-uyuşturucu madde kullanımını göstermektedir. Geniş bir tespit penceresine sahip olmasından dolayı geriye dönük madde kullanımı saç örneği ile belirlenmektedir. Ancak kemoterapi hastalarında olduğu gibi saç örnek miktarının yeterli olmadığı veya bozulmuş ya da kokuşmuş postmortem vakalarda uygun saç örneğinin alınamadığ 1 durumlarda toksikolojik analiz için tırnak örneği yararlı olabilmektedir (1). Tırnak örneği de saç örneği gibi keratinize hücrelerden meydana gelmektedir. Ksenobiyotiklerin uzun süre tırnakta birikmesi, ör-

Sorumlu Yazar: Pınar Efeoğlu Özşeker

Çukurova Üniversitesi Tip Fakültesi, Adli Tip Anabilim Dalı, Adana

E-mail:pnrefeoglu@gmail.com

Geliş: 29.03.2017 Düzeltme: 07.06.2017 Kabul: 30.10.2017 nek alırken tıbbi personel gerektirmemesi, non-invaziv olması, oda sıcaklığında saklanması ve kolay taşınabilmesi bu biyolojik örneğin saça alternatif olarak kullanılmasını sağlamıştır. Tırnak örneğinin kullanılmasının, saç örneğine göre ek bazı üstünlükleri vardır. Bunlardan ilki saçtaki gibi melanin içermediğinden, tırnak melanin konsantrasyonundan etkilenmez. Tespit edilen ilaç konsantrasyonunu yorumlarken saçın pigmentasyonu önemli bir kısıtlılık sebebidir (2,3). Tırnak saçtan daha yavaş büyümektedir, bu da önceki kullanımları araştırma ve daha düşük miktarları tespit etme olanağı sağlamaktadır. Saç, farklı safhalarda döngüsel bir büyüme hızı ile karakterize edilirken, tırnak sabit bir oranda büyümekte ve analiz sonuçlarının yorumlanmasını kolaylaştırmaktadır (4).

$\mathrm{Bu}$ çalışmada toksikolojik analizlerde alternatif olarak kullanılan tırnağın temel yapısı, tırnak içerisine ilaç ya da madde geçiş mekanizması, analitik yöntemler, tırnak kullanımın avantajları/dezavantajları ve analiz sonuçların nasıl yorumlanacağının sunulması amaçlanmıştır. 


\section{Tirnak}

\section{Tirnak Anatomisi}

İnsanda tırnağın temel görevi el ve ayak parmakların terminal falanksını korumaktır. Aynı zamanda parmak ucuna baskı yaparak dokunmaya, küçük nesneleri tutmaya ve kaşımaya yardımcı olmaktır (5). Tırnak; germinal matris, tırnak plağ1, tırnak yatağ1, tırnak katmanları, lunula ve hiponişyum bileşenlerinden oluşmaktadır.

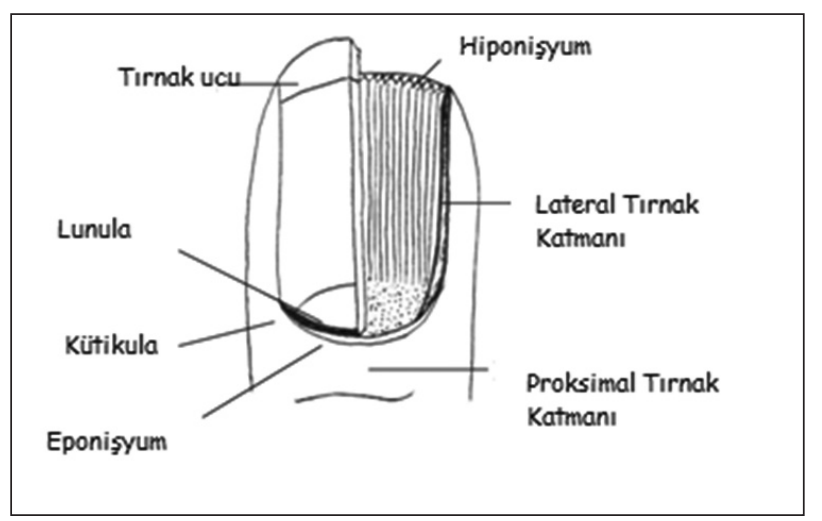

Şekil 1. Tırnak anatomisi

Germinal matris derinin altında uzanan tırnak üretiminin büyük çoğunluğunun yapıldığg 1 yerdir. Proksimal tırnak katmanıyla korunur. Germinal matris tırnak plağını oluşturan keratin hücrelerini üretir. Yeni keratin hücreleri oluştuğunda yaşlı olan keratin hücrelerini kutiküla dışına iterek yarı saydam tırnak plağını oluşturur. Büyümenin \%80'lik bölümü bu bölgede gerçekleşir. Germinal matriste melanin üretiminden sorumlu olan melanosit hücreleri yok denecek kadar azdır. Bu yüzden tırnakta pigmentasyon gerçekleşmez. Germinal matrisin boyutu ve şekli tırnak plağının kalınlığını ve şeklini belirler. Matris ne kadar uzun olursa o kadar hücre üretilir ve tırnak kalınlaşır. Matrisin şekli bireyler arasında değişmektedir (6).

Lunula yarım ay şeklinde, beyazımsı ve opaktır, matrisin en uzak bölgesidir. Bütün parmaklarda lunula görünmezken, en tutarlı başparmak ve işaret parmağında görünür. Beyaz rengi 1şığı yansıtmasının veya keratinizasyonun yetersizliğinin bir sonucudur $(6,7)$.

Tırnak plağı daha sert, saydam, çok iletken ve neredeyse şeffaftır. Birbirine sülfür bağı ile sıkı sıkıya bağl1, ölmüş keratinize hücrelerin üst üste birikmesi ile oluşur. Bu hücreler pürüzsüz bir yüzey oluşturacak kadar birbirine sıkı bağlanır. Tırnak plağı yaklaşık $0.5 \mathrm{~mm}$ kalınlığındadır, genellikle erkeklerde kadınlardan daha kalındır ve yaşla birlikte artar. Tırnak plağından geçen 1şık tırnak yatağının damarlarını yansıttığından pembe renkte görünür. Serbest uçtaki tırnak plağı tırnak yatağ 1 üzerindekinden daha incedir (8). Lunula üzerindeki tırnak plağı tırnak yatağından daha incedir (7).
Tırnak yatağı lunuladan hiponişyuma kadar uzanır. Tırnak plağına yapışan vasküler düz bir yüzeydir ve uzunlamasına epidermal kabartıdan ve dermal papillardan oluşur. Tırnak yatağının sonlandığı ve normal epidermisin başladığı tırnak plağının altındaki alan hiponişyum olarak adlandirılır (9).

Tırnak katmanları tırnak yatağını ve matrisi bakterilere karşı koruyucu bariyerler gibi davranırlar. Biri proksimal ikisi de lateral olmak üzere üç katmandan oluşur. Tırnak plağı, epidermisin ve derinin uzantısı olan, ter bezlerini içeren proksimal tırnak katmanının altından büyür. Proksimal tırnak katının epitelyumu olan eponişyum, tırnak plağına bağlanır ve büyüdükçe onunla birlikte hareket eder (6).

\section{Tırnağın Büyümesi}

Tırnaklar uzunluk ve kalınlık olmak üzere iki farklı yöne göre büyür. Tırnak plağının büyüme oranı matris hücrelerinin çoğalma hızı ile belirlenir. El tırnakları günde ortalama $0.1 \mathrm{~mm}$ oranında büyür (ayda 1.9-4.4 mm; ortalama $3 \mathrm{~mm}$ ). Yeni bir tırnağın proksimal katmanın altından 5 mm dışarı çıkması yaklaşık olarak 2 ayı, tırnağın tamamen yerine oturmas 6 ayı alır. El tırnakları ayak tırnaklarından daha hızlı ve ayak tırnakları el tırnaklarından üçte bir oranında az uzar. Dolayısı ile yeni bir ayak tırnağının büyümesi 12-18 ay sürer. Aynı elin parmaklarının tırnakları farklı oranlarda büyür. Büyüme hızı parmakların uzunluğu ile orantılıdır. İşaret parmağındaki tırnak en hızlı uzama eğilimindedir. Tırnak artan yaş, soğuk iklim koşulları, hastalık ve yetersiz beslenme ile daha yavaş uzarken dış stresler, gebelik gibi fizyolojik değişimler ile daha hızlı uzamaktadır $(6,7,10,11)$.

\section{Tirnak}

İçerisine İlaç/Uyutucu-Uyuşturucu Madde Geçiş Mekanizması

Tırnak plağının nerede ve tam olarak nasıl büyüdüğü konusunda tartışmalar olduğu için, tırnak içerisine ilaçların, kimyasalların ve uyutucu-uyuşturucu maddelerin geçiş mekanizması hala belirsizdir. Ancak en az iki geçiş mekanizmasının olası olduğu belirtilmektedir. Birincisi keratinleşme boyunca germinal matrisi besleyen kanın ve tırnak oluşumuna katkıda bulunan tırnak yatağındaki vaskülatörün tırnak plağına bu maddeleri yatay ve dikey olarak taşımasıdır. Proksimalden distal uca doğru boylamasına difüzyon boyunca büyüme ve tırnak plağını yıkayan ter ve yağ bezleri gibi biyolojik sıvılar, çevresel kontaminasyonlar bir diğer geçiş mekanizmasıdır. İlaçların fizikokimyasal özellikleri tırnağa geçişte önemli rol oynamaktadır. Moleküler ağırlık kadar olmasa da ilacın lipofilitesi ve iyonizasyon duru- 
mu tırnak içerisine geçişini etkilemektedir. Büyük molekül ağırlıklı ilaçların küçük molekül ağırlıklı ilaçlardan daha az tırnağa nüfuz ettiği gözlemlenmiştir. Kılın aksine tırnak melanin içermez ve bu sebeple renkten bağımsızdır. Ayrıca azot atomu içermeyen maddeler tırnakta saçtan daha yüksek miktarda birikebilmektedir. Örneğin Etil glukuronid ve 11-nor delta 9 THC- karboksilik asit tırnakta, saçtan sırasıyla 3 ve 4.9 kat daha yüksektir $(6,10)$.

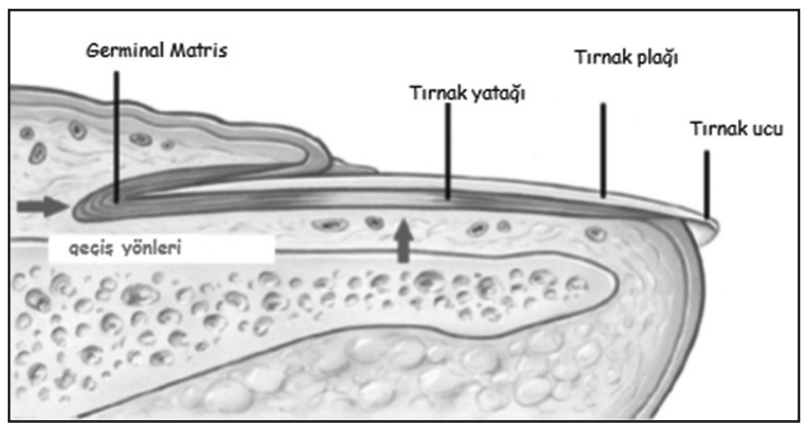

Şekil 2. Tırnak içerisine madde geçiş yönleri

\section{Tırnak ile Yapılan Çalışmalar}

Literatürde tırnakta mantar enfeksiyonlarının tedavisinde itraconazol, fluconazol ve terbinafine üzerine izleme çalışmaları yapılmıştır (11-16). Adli toksikolojik analizlerde ise ilk kez 1984 yılında Suzuki ve ark. tırnakta uyutucu-uyuşturucu madde çalışması yapmışlardır. Çalışmalarında dokuz metamfetamin kullanıcısının el ve ayak tırnaklarını tırnak makası ile keserek metamfetamin ve onun metaboliti amfetamini tespit etmişlerdir. Çalışmalarında, Metamfetamin 0.06 ila $17.7 \mathrm{ng} / \mathrm{mg}$ ve Amfetamin 0.03 ila $1.60 \mathrm{ng} / \mathrm{mg}$ aralığında değişen oranlarda bulunmuştur (17).

Diğer bir çalışmada 46 kadavranın ayak tırnaklarında kokain, benzoylekgonin, norkokain ve kokoetilenin varl1ğı kan, idrar ve mide içeriği ile kıyaslanmıştır. 23 vakanın ayak tırnaklarında 0.20 ile $140 \mathrm{ng} / \mathrm{mg}$ ve 0.30 ile $315 \mathrm{ng} /$ mg arasında değişen konsantrasyonlarda kokain ve/veya benzoylekgonin açısından pozitif iken, sadece iki vakada norkokain ve kokoetilen bulunmuştur (18).

Liu ve ark. yaptıkları çalışmada aynı bireylerden aynı anda topladıkları tırnak uç kısımlarında metamfetamin ve amfetamin konsantrasyonu ile saç örneklerinin ilk $1.5 \mathrm{~cm}$ 'lik segmentini kıyaslamış ve saçta tırnaktan daha düşük miktarda bulmuşlardır. Tırnağın uç kısmındaki ve saçtaki amfetamin/metamfetamin konsantrasyon oranının kıyaslanabileceğini; $0 ., 4 ., 8$. ve 12 . haftalarda toplanan tırnaklardaki metamfetamin miktarının bir düzen içerisinde azaldığını ifade etmişlerdir (19). Jenkins ve Engelhart postmortem vakalarda toplanan tırnak örneklerinde opiyat ve kokain metabolitlerinin tespitini çalışmışlardır. Kokain metabolit konsantrasyonları sağ ve sol taraflar arasında önemli ölçüde fark olmamasına rağmen el tırnaklarında tespit edilen miktar ayak tırnaklarınınkinden yaklaşık olarak 7-20 kat daha büyük bulunmuştur. Aynı zamanda yıkama sularındaki majör analitler kokain ve benzoylekgonin olup; kokain, benzoylekgonin, metilekgonin, norkokain ve kokoetilen için tırnakta tespit edilen miktar yıkama çözeltilerinden daha yüksek saptanmıştır. Kokain ve metabolitlerinin sonuçlarında olduğu gibi sağ ve sol bölümler arasındaki farklar önemsiz bulunmuştur. El tırnaklarındaki konsantrasyon 6-Asetilmorfin (6-AM) ve morfin için ayak tırnaklarından yaklaşık olarak 30 kat fazla bulunmuştur (20). Hem kokain hem de opiyat çalışmasında kan ve tırnak konsantrasyonları arasında korelasyon bulunmamıştır. Lemos ve ark. ise el tırnaklarında RIA ve GC/ MS ile esrarın ekstraksiyonu ve tespiti ile ilgili ilk çalışmayı yapmışlardır (21). Tetrahidrokarboksilik asitin (THCCOOH), saç analizleri (\%47) ile kıyaslandığında tırnakta (\%57) daha yüksek oranda bulunduğu gösterilmiştir (22).

Min ve ark. $10 \mathrm{mg}$ tek doz oral zolpidem alımından sonra tırnakta zaman takibi yapmışlar, ilk ve ikinci hafta ve bunu takiben 20 hafta boyunca her iki haftada bir el tırnakları, ayak tırnakları ise uzamanın oranına bağlı olarak ikinci ve dördüncü haftalardan sonra tırnak makası ile keserek toplanmıştır. Zolpidem el tırnaklarında ilk haftadan 18. haftaya kadar, ayak tırnaklarında 2 haftadan sonra tespit edilmiş ve ortalama zolpidem konsantrasyonu ayaklarda el tırnaklarından daha yüksek bulunmuştur. Zolpidemin ayak tırnaklarındaki maksimum konsantrasyon 2.94 ve $3.29 \mathrm{pg} / \mathrm{mg}$ arasında ve Zolpidemin tek dozu el tırnaklarının tümü alındığında en erken 24 saatten 3.5 aya kadar tespit edilebildiğini bildirmişlerdir. Bu çalışma ilaçla kolaylaştırılmış cinsel saldırı vakalarında saç örneklerine tamamlayıcı ve alternatif bir örnek olabileceğini göstermiştir $(23,24)$.

\section{Tirnakta Toksikolojik Analiz}

Keratinize matrisin karmaşık yapısı ve ölçülmesi gereken düşük konsantrasyonlar (ng/mg - pg/mg aralığı) nedeniyle spesifik analitik yöntemlerle beraber kapsamlı bir örnek hazırlama işlemi gereklidir. Numune hazırlama prosedürü; dekontaminasyon, homojenizasyon ve ekstraksiyon işlemlerini içermektedir. Şekil 3 'te numune hazırlama basamakları gösterilmektedir. 


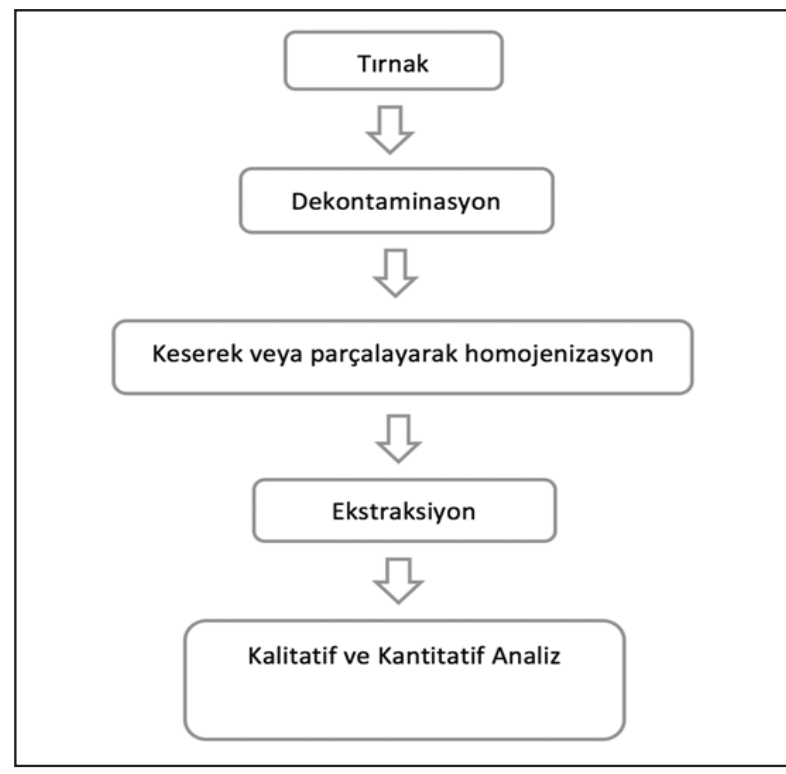

Şekil 3. Tırnak hazırlama basamakları

En çok tercih edilen yıkama işlemi dış kontaminasyonun tamamen giderilmesini mümkün kılan prosedürdür. Diş kontaminasyonu uzaklaştırmak için tırnak örneği metanol, aseton, su gibi uygun çözücü ile oda sicaklığında yıkanır. Bu yıkama işleminden sonra oda sıcaklığında kurutulan tırnak tartılarak toz haline getirilir. Homojenize olan tırnak kat1-sıvı ya da sivi-sıv1 ekstraksiyon yöntemi ile matristen ekstrakte edilir. Benzer şekilde, en uygun ekstraksiyon prosedürü, herhangi bir parçalanmaya neden olmaksızın, numune matrisinden ilgili analitlerin $\% 100$ çıkarılmasına izin verecektir.

Literatürde tırnakta kokain, esrar, opiyat, methadon, amfetamin ve türevleri, sedatif ilaçlar gibi pek çok maddenin ekstraksiyonu ve yöntem validasyonu çalışılmıştır. Yapılan çalışmalarda 5-100 mg arasında tartılan tırnak örnekleri ilk olarak üçer kez sırasıyla $5 \mathrm{ml}$ distile su ve metanol ile yıkanarak oda sıcaklığında kurumaya bırakılmıştır. Boncuklu doku parçalayıcı kullanılarak numune toz haline getirilmiştir. Genellikle ultrasonik banyoda 55 ${ }^{\circ} \mathrm{C}$ 'de 1 saat ya da $1 \mathrm{M} \mathrm{NaOH}$ ile $55^{\circ} \mathrm{C}$ 'de 30 dakika inkübasyona bırakılmıştır. Alkali hidrolizini takiben asit hidrolizi yapılmıştır. Bu maddelerin geri kazanım oranlar1 \%75-98 oranında bulunmuştur (25-30). Kat1-sıv1 veya sıv1-sıv1 ekstraksiyon yapılıp elüent GC/MS ve GC-MS/ MS'e verilecekse türevlendirme işlemi yapılıp, LC-MS/ MS'e ise direkt enjekte edilmiştir (31).

\section{Rutin Uygulamalar}

Çukurova Üniversitesi Tıp Fakültesi Adli Tıp Anabilim Dalı Adli Toksikoloji laboratuvarında yapılan tırnak uygulamalarına bakıldığında tırnak örnekleri genellikle adli makamlardan gelmektedir.
Olgu 1: 38 yaşında erkek şahıstan Cumhuriyet Savc1lığı Uyuşturucu Suçları Soruşturma Bürosu kan, idrar, saç ve tırnak örneklerinin alınmasını ve bu biyolojik örneklerde uyutucu-uyuşturucu madde olup olmadığının tespiti istenmiştir. Şahsın saç örneği posterior verteks bölgesinden deriye olabildiği kadar yakın, tırnak örnekleri ise tırnak makası ile sağ ve sol el tırnaklarının ucundan kesilmesi ile alınmıştır. Şahsın idrar pH'sı 5.5, yoğunluğu 1.010 ölçülmüştür. Cetvel ile ölçülen saç uzunluğu $2.2 \mathrm{~cm}$, tırnak ucu uzunluğu ise $0.2 \mathrm{~cm}$ olarak kaydedilmiştir. Yapılan toksikolojik analiz sonucunda şahsın kan ve idrar örneğinde herhangi bir uyutucu-uyuşturucu madde saptanamamıştır. Şahsın saç ve tırnak örneklerinde kokain ve benzoylekgonine (kokain metaboliti) pozitif bulunmuştur.

Olgu 2: 26 yaşındaki erkek şahıstan geçmişe dönük madde kullanımını belirlemek için saç ve tırnak örneğinin alınması istenmiştir. Şahsın saç ve tırnak örneği cetvel ile ölçülerek saç uzunluğu $1.5 \mathrm{~cm}$ ve tırnak uzunluğu 0.2 $\mathrm{cm}$ gelmiştir. Yapılan toksikolojik analiz sonucunda saç örneğinde uyutucu-uyuşturucu madde tespit edilmezken tırnak örneğinde MDMA (Ecstasy) pozitif bulunmuştur.

\section{Tirnakta Toksikolojik Analiz Sonuçlarının Yorumlanması}

Hassas ve seçici analitik yöntemlerin ortaya çıkması kan ve idrara alternatif olabilecek saç ve tırnak gibi biyolojik örneklerin kullanımını arttırmıştır. Tırnakta yapılan örnekleme teknikleri ve analiz yöntemlerinin standardize olmaması ayrıca metot validasyonundaki eksiklikler nedeniyle de bulguları kıyaslamak zordur. Yaşayan kişilerden tırnak makası ile tırnak ucu alınırken postmortem vakalarda tırnak köküyle beraber tüm tırnak alınabilmektedir. Tırnak yatağı boyunca lunuladan tırnağın serbest kısmına ilaç geçişi olmaktadır. Ancak tırnak içerisine madde geçişinin kesin mekanizması bilinmediği için kalitatif sonuçların yorumlanması zor olmaktadır.

Günümüzde yeni nesil psikoaktif maddelerinin sayıs1 her geçen gün artmaktadır. Kimyasal yapılarının sürekli ve hızla değişmesi, vücutta emilimi ve dağılımı hakkında verinin çok az olması bu maddelerin biyolojik örneklerde tespitini zorlaştırmaktadır. Özellikle sentetik kannabinoidler lipofilik maddelerdir ve solunduktan sonra akciğer yoluyla absorbe edilerek hızla yağ dokusuna yayılır ve birikebilir. Bu da uygulama sonrası kandaki ana ilaç konsantrasyonunun hızlı bir şekilde azalmasına neden olmaktadır (32). Tırnak içerisine maddelerin geçiş yolu temelde kılcal damarlar aracılığı ile olmasından ötürü bu yeni nesil tasarım maddeler tırnak örneğinde tespit edilemeyebilir.

Pek çok ilaç için doz-cevap ilişkisi olmasına rağmen tırnakta tespit edilen konsantrasyon ile kanda tespit edilen konsantrasyon arasında korelasyon bulunmamaktadır. 
Reçeteli ilaçlar, uyutucu-uyuşturucu maddeler hem el hem de ayak tırnaklarında tespit edilebilir ve ölçülebilir. Amfetamin hariç bu maddelerin ortalama konsantrasyonu el tırnaklarında ayak tırnaklarından daha yüksek oranda bulunmaktadır (33).

Tırnak örneklerinde analiz sonuçlarını yorumlarken ter gibi dış faktörler ve çevresel kontaminasyon düşünülmelidir. Kokain tozunu elledikten sonra tırnakların uç kısmında tutulan kokain eli yıkadıktan sonra veya terleme ile benzoilekgonine dönüşür. El tırnaklarında yıkama çözeltilerinde benzoylekgonin miktarının daha yüksek çıkması bununla açıklanabilmektedir. Kan ve idrar gibi diğer biyolojik örneklerde kokain metabolitlerinin bulunması kişinin bu maddeyi kullanımının göstergesi olmasına rağmen tırnakta böyle olmayabilir. Kokain enzimatik olmayan hidroliz yoluyla benzoylekgonine dönüşebilir. Böylece dış kontaminasyondan $\mathrm{m} 1$ absorplandığı yoksa madde kullanımının kan vasıtasıyla mı tırnak içerisine geçip geçmediğini tanımlamak mümkün olamayabilir. Norkokain ve kokoetilen gibi diğer kokain metabolitlerinin varlığ1 tırnakta bu ayrımı yapmaya izin verebilmektedir. Tırnak analizlerinde madde kullanımı ve dış kontaminasyon ayrımı için norkokain faydalı bir analit olabilir (6). Anhidroekgonin metil esterin el tırnaklarında saptanması krak kokain dumanına maruz kalmayı düşündürürken, aynı bulgu ayak tırnaklarındaki aktif kullanımı gösterir (4).

Benzer problemler opiyat sonuçlarını değerlendirirken de geçerlidir. El ve ayak tırnaklarında 6-asetil morfin ve morfin tespit edilmesine rağmen bunlardan birinin varlığı eroin kullanımının dış kontaminasyon mu yoksa madde kullanımından $m ı$ kaynaklandığı bilgisini vermez. Eroin de enzimatik olmayan hidroliz ile 6-AM ve morfine dönüşür. Sadece enzimatik yolla oluşan morfin glukronid metabolitleri bu ayrımın yapılmasına yardımcı olabilir (6). MDA/MDMA, EDDP/Metadon gibi bazı maddeler için de tırnak ve saç örneklerinde ilaç ve ana metabolit oranı arasinda benzer konsantrasyon oranları tespit edilmiştir. Postmortem vakalardan toplanan kıl ve tırnak örneklerinde bulunan maddelerin konsantrasyonlarının k1yaslanamayacağını ve farklı ilaçların farklı segmentlerde birikebileceğini göstermişlerdir (34).

\section{Sonuç}

Amfetamin, metamfetamin, kannabinoid, kokain ve metabolitleri, doping maddeleri, fluconazole, itaconazole, ketoconazole, morfin, nikotin/kotinin, alüminyum, arsenik, kadmiyum, cıva, kurşun gibi iz elementler saçta ve tırnakta tespit edilebilmektedir (35). Saç örneklemesinin uygun olmadığı durumlarda tırnak analizleri, geriye dönük madde kullanımının tespiti için faydalı bir biyolojik örnektir. İlaçla kolaylaştırılmış cinsel saldırı suçlarında alkol, uyuşturu- cu madde veya farmasötik madde kullanımının tespitinde, rutin kan ve idrar örnekleri çalışılmaktadır. Mağdurların hastane ve adli mercilere başvurularının geç olması durumunda ise tırnak örnekleri kullanılabilmektedir.

İleride yapılacak araştırmalarda, tırnakta metot validasyonlarının geliştirilerek standardize yöntemlerin oluşturulması gerekmektedir. Ayrıca, segmentel tırnak analizi ile ilgili yapılan çalışmaların artmasıyla ilaç ya da yasadışı maddelerin ne zaman alındığı hakkında yorum yapabilmek mümkün olabilecektir.

\section{Kaynaklar}

1. Pragst F, Balikova MA. State of the art in hair analysis for detection of drug and alcohol abuse. Clin Chim Acta,2016; 370: 17-49. DOI: 10.1016/j.cca.2006.02.019

2. Kronstrand R, Förstberg-Peterson S, Kägedal B, Ahlner J, Larson G. Codeine concentration in hair after oral administration is dependent on melanin content, Clin Chem, 1999; 45: 1485-1494.

3. Testorf MF, Kronstrand R, Svensson SPS, Lundström I, Ahlner J. Characterization of [3-H] flunitrazepam binding to melanin. Anal Biochem, 2001;298:259-264. DOI: 10.1006/abio.2001.5364

4. Cappelle D, Yegles M, Neels H, L. N. van Nuijs A, De Doncker M, Maudens K, Covaci A, Crunelle CL. Nail analysis for the detection of drugs of abuse and pharmaceuticals: a review. Forensic Toxicol, 2015; 33: 12-36. DOI: 10.1007/s11419-014-0258-1

5. Lemos NP. Analysis of Bile \& Nail as Alternative Biological Specimens in Forensic Toxicology (Doctorate Thesis). University of Glasgow, 1996: 23-30.

6. Garside D. Drugs-of-Abuse in Nails. In: Drug Testing in Alternate Biological Spicemens. Jenkins AJ, Caplan YH, Editors. Forensic Science \&Medicine, Humana Press, Chapter 3; 2007;44-48. DOI: 10.1007/978-1-59745-318-9 3

7. Zaias N. The nail in health and disease. MTP Press, Spectrum Publications, 1980 Chapter 1, 1-18 Florida. DOI: 10.1007/978-94-011-7846-4

8. Johnson M, Shuster S. Continuous formation of nail along the bed. British Journal of Dermatology, 1993; 128 (3): 277 280. DOI: 10.1111/j.1365-2133.1993.tb00171.x

9. Gür G. Yeni Başlayanlar için Tırnak Cerrahisi, Türkderm 2010; 44: 123-7. DOI: 10.4274/turkderm.44.123

10. Palmeri A, Pichini S, Pacifici R, Zuccaro P, Lopez A. Drugs in Nails. Clin Pharmacokinet 2000, 38(2):95-110. DOI: 10.2165/00003088-200038020-00001

11. Willemsen M, De Doncker P, Willems J, Woestenborghs R, Van de Velde V,Heykants J, Van Cutsem J, Caunwenbergh G, Roseeuw D. Post treatment itraconazole levels in the nail: New implications for treatment in onychomycosis. Journal of American Academy of Dermatology,1992, 26;5(1):731-735. DOI: 10.1016/0190-9622(92)70102-L

12. Gauwenbergh G, Degreef H, Heykants J, Woestenborghs R, Van Rooy P and Haeverans K. Pharmacokinetic profile 
of orally administered itraconazole in human skin. J. Am. Acad. Dermatol,1988;18: 263-268. DOI: 10.1016/S01909622(88)70037-7

13. Hay RJ. Pharmacokinetic evaluation of fluconazole in skin and nails. Int J Dermatol 31(Suppl 2), 6-7, 1992

14. Faergemann J and Laufen H. Levels of fluconazole in normal and diseased nails during and after treatment of onychomycoseis in toe-nails with fluconazole $150 \mathrm{mg}$ once weekly. Acta Dermatol. Venereol, 1996; 76: 219-221.

15. Matsumoto T, Tanuma H, Kaneko S, Takasu H and Nishiyarna S. Clinical and pharmacokinetic investigations of oral terbinafine in patients with tinea unguium. Mycoses, 1995;38: 135-144. DOI: 10.1111/j.1439-0507.1995.tb00037.x

16. Schatz F, Brautigam M, Dobrowolski E, 1. Leffendy, Haberl $\mathrm{H}$, Mensing $\mathrm{H}$ et al. Nail incorporation kinetics of terbinafine in onychomycosis patients. Clin. Exp. Dermatol,1995; 20: 377-38. DOI: 10.1111/j.1365-2230.1995.tb01353.x

17. Suzuki O, Hattori H, Asano M. Nails as useful materials for detection of methamphetamine or amphetamine abuse. Forensic Sci Int.1984; 24: 9-16. DOI: 10.1016/03790738(84)90146-4

18. Engelhart DA, Lavins ES, Sutheimer CA. Detection of drugs of abuse in nails. J Anal Toxicol, 1998;22: 314-318. DOI: $10.1093 /$ jat $/ 22.4 .314$

19. Lin DL, Yin RM, Liu HC, Wang CY, Liu RH. Deposition characteristics of metamphetamine and amphetamine in fingernail clippings and hair sections. Journal of Analytical Toxicology,2004;28: 411-417. DOI: 10.1093/jat/28.6.411

20. Engelhart DA, Jenkins AJ. Detection of cocaine analytes and opiates in nails from postmortem cases. Journal of Analytical Toxicology,2002;26: 489-492. DOI: 10.1093/ jat/26.7.489

21. Lemos NP, Anderson RA, Robertson JR. Extraction and determination of cannabis in fingernails by RIA and GC/ MS. Journal of Analytical Toxicology,1999. DOI: 10.1093/ jat/23.3.147

22. Jones J, Jones M, Plate C, Lewis D. The detection of THCA using 2-dimensional gas chromatography-tandem mass spectrometry in human fingernail clippings: method validation and comparison with head hair. Am J Anal Chem 2013; 4: 1-8. DOI: 10.4236/ajac.2013.410A2001

23. Madry MM, Steuer AE, Binz TM, Baumgartner MR and Kraemer T. Systematic investigation of the incorporation mechanisms of zolpidem in fingernails. Drug Testing and Analysis, 2014;6: 533-541. DOI: 10.1002/dta.1558

24. Lemos NP, Anderson RA, Robertson JR. The analysis of methadone in nail clippings from patients in a methadonemaintenance program. Journal of Analytical Toxicology, 2000;24: 656-660. DOI: https://doi.org/10.1093/jat/24.7.656
25. Hang C, Ping X, Min S. Long-term follow-up analysis of zolpidem in fingernails after a single oral dose. Anal Bioanal Chem, 2013;405:7281-7289. DOI: 10.1007/s00216013-7188-3

26. Valente-Campos S, Yonamine M, De Moraes Moreau RL, Silva OA. Validation of a method to detect cocaine and its metabolites in nails by gas chromatography- mass spectrometry. Forensic Science International, 2006;159:218-222. DOI: 10.1016/j.forsciint.2005.07.021

27. Irving RC, Dickson SJ. The detection of sedatives in hair and nail samples using tandem LC-MS-MS. Forensic Science International, 2007;166: 58-67. DOI: 10.1016/j.forsciint.2006.03.027

28. Kim JY, Cheong JC, Kim MK, II Lee J, In MK. Simultaneous determination of amphetamine-type stimulants and cannabis in fingernails by gas chromatography-mass spectrometry. Archieves of Pharmacal Research, 2008;31(6):805813. DOI: $10.1007 / \mathrm{s} 12272-001-1230-5$

29. Kim JY, Shin SH, In KM. Determination of amphetaminetype stimulants, ketamine and metabolite in fingernails by gas chromatography-mass spectrometry. Forensic Science International, 2010;194:108-114. DOI: 10.1016/j.forsciint.2009.10.023

30. Kim JY, Cheong JC, II Lee J, Son JH, In MK. Rapid and simple GC-MS Method for determination of psychotropic phenylalkylamine derivates in nails using micro-pulverized extraction. Journal of Forensic Sciences,2012;57(1):228-233. DOI: 10.1111/j.1556-4029.2011.01913.x

31. Madej KA. Analysis of meconium, nails and tears for determination of medicines and drugs of abuse. Trends in anaytical Chemistry,2010;29(3):246-259. DOI: 10.1016/j. trac.2010.01.005

32. UNODC. Synthetic cannabinoids in herbal products. Erişim: (https://www.unodc.org/ documents/scientific/Synthetic_Cannabinoids.pdf) Erişim tarihi:05.06.2017.

33. Shu I, Jones J, Jones M, Lewis D, Negrusz A. Detection of drugs in nails: Three year experience. Journal of Analytical Toxicology,2015; 30: 624-628. DOI: 10.1093/jat/bkv067

34. Krumniegel F, Hastedt M, Westerndorf L, Niebel A, Methling M, Parr MK, Tsokos M. The use of nails as an alternative matrix for the long-term detection of previous drug intake: validation of sensitive UHPLC-MS/MS methods for the quantitation of 76 substances and comparison of analytical results for drugs in nail and hair samples. Forensic Sci Med Pathol, 2016; 12(4): 416-434. DOI: 10.1007/s12024016-9801-1

35. Daniel III CR, Piraccini BM, Tosti A. The nail and hair in forensic science. J Am Acad Dermatol, 2004;50(2):258261. DOI: $10.1016 /$ j.jaad.2003.06.008 